\title{
DIGITALIZATION OF BUSINESS REGISTER - ONE YEAR AFTER
}

\author{
Željka Bregeš * \\ Tina Jakupak **
}

\begin{abstract}
Digitalization is considered to be necessary for the achievement of the European Union's aim of modernization of business registers in EU countries. This paper aims to contribute to the improvement of digitalization of business register after one year experience. Authors take an insight into the process. First, the authors identify key issues and differences between countries. The authors focus on digitalization attempt. Then, by comparing different business registers authors find different solutions. Finally, the authors conclude this paper of the implementation of digital solutions from the future perspective. The authors in this paper study the new system introduced in June 2017 and analyze it a year after interconnection business registers in all EU countries. Is it really interconnection of business registers? Is it possible to search for data and information on companies registered in all EU countries? Did we make a step forward regarding the digitalization of the market and business register? This paper is a sequel to the paper Digitalization of Business Register from the judge's perspective due to the author's position and everyday challenges as the judges at Commercial court in Zagreb, Courts' Register Department.
\end{abstract}

KEYWORDS: EU company law; business register; court register, digitalization; interconnection

* Commercial Court in Zagreb, judge; zeljka.breges@tszg.pravosudje.hr

** Commercial Court in Zagreb, judge; tina.jakupak@tszg.pravosudje.hr 


\section{INTRODUCTION}

The importance of digitalization of Business Register ${ }^{1}$ in EU Company law (and corporate governance) is the main topic in our surroundings - commercial courts. Transparency of data and information on the companies and its background contributes to the protection of shareholders rights, as well as the rights of third parties ${ }^{2}$. Authentical and prompt information is everything in today's world of digitalization, internet, and new technologies, as well it is in business. The high role of data digitalization, including transparency of data, arises in cases of cross-border mergers (and other cross-border activities of the companies). In the last paper $^{3}$ authors have analyzed newly introduced cooperation of business registers at European level ${ }^{4}$. In this paper, the authors will give an overview of the digitalization of Business and Companies/Court registers in the EU within last year with an emphasis on Croatia.

Digitalization of company law changes in the company law related procedures to move from paper-based processes where a physical presence before authority is required to end-to-end direct online ${ }^{5}$.

The interconnection of central, commercial and companies registers is a measure required to create a more business-friendly legal and fiscal environmen$t^{6}$ It should contribute to fostering the competitiveness of European business by reducing administrative burdens and increasing legal certainty and thus contributing to an exit from the global economic and financial crisis, which is one of the priorities of the agenda of Europe 2020. It should also improve cross-border communication between registers by using innovations in information and communication technology.

\footnotetext{
In European company law business registers is ,central, commercial or companies register", see article 16. Directive (EU) 2017/1132 of the European Parliament and of the Council of 14 June 2017 relating to certain aspects of company law, OJ L 169, 30.6.2017, p. 46-127

2 Green Paper-The interconnection of business registers $\{$ SEC(2009) 1492\}-COM/2009/0614 final

3 Bregeš, Željka; Jakupak, Tina (2017): DIGITALIZATION OF BUSINESS REGISTER, InterEULawEast: journal for the international and European law, economics and market integrations, Volume 4, No. 2, December 2017., page 91.-99.

4 The European Access Point to the interconnection of the national business registers (Business Registers Interconnection System - BRIS) is available on the European e-Justice Portal from 8 June 2017

5 Final Report - Assessment of the impacts of using digital tools in the context of cross-border company operations

6 Preamble, line 23, of Directive (EU) 2017/1132 of the European Parliament and of the Council of 14 June 2017 relating to certain aspects of company law.
} 


\section{EU REGULATORY FRAMEWORK}

Relevant Directives and Regulations in EU establishing the EU-level regulatory framework with regard to the use of digital tools in the context of company law operations (references to articles presenting directly relevant analyses to the topic of digitalization of company law) ${ }^{7}$ are: 1 . Directive $82 / 891 / \mathrm{EEC}$ of 17 December 1982 based on Article 54 (3) (g) of the Treaty, concerning the division of public limited liability companies; 2. Directive 89/666/EEC of 21 December 1989 concerning disclosure requirements in respect of branches opened in a Member State by certain types of company governed by the law of another State; 3. Directive 95/46/EC of the European Parliament and of the Council of 24 October 1995 on the protection of individuals with regard to the processing of personal data and on the free movement of such data; 4 . Directive 2001/86/EC of the Council of 8 October 2001 complementing the Statute for a European company with regard to the involvement of employees; 5. Council Regulation (EC) No1435/2003 of 22 July 2003 on the Statute for a European Cooperative Society (SCE); 6. Directive 2004/109/EC of the European Parliament and of the Council of 15 December 2004 on the harmonization of transparency requirements in relation to information about issuers whose securities are admitted to trading on a regulated market and amending Directive 2001/34/EC; 7. Directive 2005/56/EC of the European Parliament and of the Council of 26 October 2005 on cross-border mergers of limited liability companies; 8. Directive 2007/36/EC of the European Parliament and of the Council of 11 July 2007 on the exercise of certain rights of shareholders in listed companies; 9. Directive 2009/101/EC of the European Parliament and of the Council of 16 September 2009 on coordination of safeguards which, for the protection of the interests of members and third parties, are required by Member States of companies within the meaning of the second paragraph of Article 48 of the Treaty, with a view to making such safeguards equivalent; 10. Directive 2009/102/EC of the European Parliament and of the Council of 16 September 2009 in the area of company law on single-member private limited liability companies; 11. Directive 2011/35/EU of the European Parliament and of the Council of 5 April 2011 concerning mergers of public limited liability companies; 12. Directive 2012/17/EU of the European Parliament and of the Council of 13 June 2012 amending Council Directive 89/666/EEC and Directives 2005/56/EC and 2009/101/EC of the European Parliament and of the Council as regards the interconnection of central, commercial and companies registers; 13. Directive 2012/30/EU of the European Parliament and of

7 Assessment of the impacts of using digital tools in the context of cross-border company operations - Final Report, December 2017 
the Council of 25 October 2012 on coordination of safeguards which, for the protection of the interests of members and others, are required by Member States of companies within the meaning of the second paragraph of Article 54 of the Treaty on the Functioning of the European Union, in respect of the formation of public limited liability companies and the maintenance and alteration of their capital, with a view to making such safeguards equivalent; 14. Directive 2013/34/EU of the European Parliament and of the Council of 26 June 2013 on the annual financial statements, consolidated financial statements and related reports of certain types of undertakings, amending Directive 2006/43/EC of the European Parliament and of the Council and repealing Council Directives 78/660/EEC and 83/349/EEC; 15. Directive (EU) 2015/849 of the European Parliament and of the Council of 20 May 2015 on the prevention of the use of the financial system for the purposes of money laundering or terrorist financing, amending Regulation (EU) No 648/2012 of the European Parliament and of the Council, and repealing Directive 2005/60/EC of the European Parliament and of the Council and Commission Directive 2006/70/EC.

General analyses of digitalization in the context of company law operations at the EU level are: ${ }^{8} 1$. In-depth analysis for DG for Internal Policies (2016), What are the issues relating to digitalization in company law - provides an overview of the current and potential future directions for EU adoption of digital tools 9 ; 2. Report on digitalization in company law by the Informal Company Law Expert Group (ICLEG) ${ }^{10} ; 3$. Communication from the Commission to the European Parliament, the Council, the European Economic and Social Committee and the Committee of the Regions (2012) Action Plan: European company law and corporate governance - a modern legal framework for more engaged shareholders and sustainable companies; 4. The Commission has a web portal that allows identification (per Member State) of the time, cost and relevant local authorities in the context of registering a company ${ }^{11}$; 5 . The Commission's Impact Assessment accompanying the Proposal for a Directive of the European Parliament and of the Council on single-member private limited liability

\footnotetext{
8 Assessment of the impacts of using digital tools in the context of cross-border company operations, Final Report, EC, December 2017

9 http://www.europarl.europa.eu/RegData/etudes/IDAN/2016/556961/IPOL_IDA(2016) 556961_EN.pdf

$10 \mathrm{http} / / / \mathrm{ec}$. europa.eu/justice/civil/files/company-law/icleg-report-on-digitalisation-24march-2016_en.pdf

11 http://europa.eu/youreurope/business/start-grow/start-ups/index_en.htm
} 
companies (2014) ${ }^{12}$; 6. Keynote address by Vēra Jourová, Commissioner for Justice, Consumers and Gender Equality, on Company Law in the Digital Age $(2015)^{13}$; 7. Proposal for a Directive of the European Parliament and of the Council on single-member private limited liability companies (2014).

The initiative of the European Commission with respect to the use of digital tools and processes is online registration and filing, multiple submissions of company information and limited access to free of charge company information. New rules on these issues would be modifying and complementing the existing company law acquis $^{14}$. To recall, the current EU legal framework does not provide rules for online registration but it includes certain provisions on the online filing of information by companies. Furthermore, the existing rules require companies to file the same data twice, in some member states may take more. As to the access to company information, although it is now possible to search online for information from all EU business registers via one single European access point thanks to the interconnection of business registers (BRIS), only a very limited set of company data is available free of charge.

12 http://eur-lex.europa.eu/legal-content/EN/TXT/PDF/?uri=CELEX:52014SC0124\&from $=\mathrm{EN}$

13 http://ec.europa.eu/justice/events/company-law 2015/files/20151002_cvj_speech_company_law_sc_en . pdf

14 Horak, Hana; Dumančić, Kosjenka, Usklađivanje u području prava društava Republike Hrvatske s pravnom stečevinom EU, Pravo i porezi, 20:5/2011, str. 86-93. Isto Horak, Hana; Dumančić, Kosjenka, Harmonisation of the Croatian Company Law with acquis communitare of the European Union u: Horak, Hana; Bodiroga Vukobrat Nada; Dumančić, Kosjenka; Šafranko, Zvonimir (ur.), Hrvatsko i europsko pravo društava/Croatian\&European Company Law, Zbornik radova/Proceedings, Zagreb, 2012. str. 7., dostupno na pars.rs/ddownload/_ params/file_id/4198.html, [8. 4. 2014]. 


\section{FEW MORE NEW DIRECTIVES ${ }^{15}$}

The system of interconnection of business registers was created with Directive 2012/17/EU ${ }^{16}$. This directive is now part of the codified Directive (EU) $2017 / 1132^{17}$ relating to certain aspects of company law.

The use of digital tools in this context has been enforced by Directive 2009/101/ $\mathrm{EC}^{18}$, under which the Member States must ensure that certain information can be filed by electronic means, namely: the company's constitution; changes to the constitution; details of those authorized to represent the company in dealings with third parties and legal proceedings, as well as those who administer, supervise and control the company; the capital subscribed; the appointment of a liquidator; termination of a liquidation; accounting documents; chang-

15 Sixth Council Directive 82/891/EEC of 17 December 1982 based on Article 54 (3) (g) of the Treaty, concerning the division of public limited liability companies OJ L 378, 31.12.1982, p. 47-54; Eleventh Council Directive 89/666/EEC of 21 December 1989 concerning disclosure requirements in respect of branches opened in a Member State by certain types of company governed by the law of another State OJ L 395, 30.12.1989, p. 36-39; Directive 2005/56/EC of the European Parliament and of the Council of 26 October 2005 on cross-border mergers of limited liability companies (Text with EEA relevance) OJ L 310, 25.11.2005, p. 1-9; Directive 2009/101/EC of the European Parliament and of the Council of 16 September 2009 on coordination of safeguards which, for the protection of the interests of members and third parties, are required by Member States of companies within the meaning of the second paragraph of Article 48 of the Treaty, with a view to making such safeguards equivalent (Text with EEA relevance) OJ L 258, 1.10.2009, p. 11-19; Directive 2011/35/EU of the European Parliament and of the Council of 5 April 2011 concerning mergers of public limited liability companies Text with EEA relevance OJ L 110, 29.4.2011, p. 1-11; Directive 2012/30/EU of the European Parliament and of the Council of 25 October 2012 on coordination of safeguards which, for the protection of the interests of members and others, are required by Member States of companies within the meaning of the second paragraph of Article 54 of the Treaty on the Functioning of the European Union, in respect of the formation of public limited liability companies and the maintenance and alteration of their capital, with a view to making such safeguards equivalent Text with EEA relevance OJ L 315, 14.11.2012, p. 74-97

16 Directive 2012/17/EU of the European Parliament and of the Council of 13 June 2012 amending Council Directive 89/666/EEC and Directives 2005/56/EC and 2009/101/EC of the European Parliament and of the Council as regards the interconnection of central, commercial and companies registers, OJ L 156, 16.6.2012, p. 1-9.

17 Directive (EU) 2017/1132 of the European Parliament and of the Council of 14 June 2017 relating to certain aspects of company law (Text with EEA relevance. )-OJ L 169, 30.6.2017, p. $46-127$

18 Directive 2009/101/Ec of the European Parliament and of the Council of 16 September 2009 on coordination of safeguards which, for the protection of the interests of members and third parties, are required by Member States of companies within the meaning of the second paragraph of Article 48 of the Treaty, with a view to making such safeguards equivalent, $O J L$ $258,1.10 .2009, p .11-19$., no longer in force 
es to the registered office and striking off the company and any declaration of nullity by the courts. Directive 2009/101/EC also requires companies or their representatives to file company information (e.g. in a national gazette) and includes an option for Member States to allow companies to meet this requirement electronically. The digitalization of this operation provides essential visibility into different organizations. In addition, it reduces the risk of shareholders and other stakeholder organizations being defrauded through not having full access to relevant company information.

Directive 2017/1132 is a partial and not complete answer to the concerns that the European Commission has expressed in Action Plan from 2012. The aim is legal certainty. It codifies six previous mentioned Directives that are repealed $^{19}$. These directives had been substantially amended several times and it was difficult to know the exact rules that were in force. To dispel the doubts, the Commission decided to merge their current versions, looking for clarity and rationality. It holds that their provisions will now be easier to interpret, transpose and apply. One of them was Directive 2009/101/EC. The only amendments it introduces are the formal ones that the codification technique requires. It should do more.

\section{THE COURT REGISTER IN CROATIA}

In accordance with Directive 2009/101/EC ${ }^{20}$, and its changes, Croatia has the Court Register. It is a central, commercial and companies' register established in Croatia.

In the Republic of Croatia, the Court register is managed by the commercial courts $^{21}$. The Court register is a public book containing data and documents on entities which have to be entered in the register by law $^{22}$. Each court that carries out registration is responsible for the authenticity of its entries in the register $^{23}$. The following are entered in the Court register: public trading companies (javna trgovačka društva), limited partnerships (komanditna društva), economic interest group (gospodarska interesna udruženja), joint-stock com-

\footnotetext{
19 Ibid. 15

$20 \quad$ Ibid. 18

${ }_{21}$ There are 8 commercial courts in Croatia situated in Zagreb, Rijeka, Split, Zadar, Pazin, Bjelovar, Osijek, Varaždin

22 Zakon o sudskom registru - Court Register Act - Official Gazette no 1/1995, 57/1996, 1/1998, 30/1999, 45/1999, 54/2005, 40/2007, 91/2010, 90/2011, 148/2013, 93/2014, 110/2015

23 https://e-justice.europa.eu/content_business_registers_in_member_states-106-hr-en. do?member $=1$
} 
panies (dionička društva), limited liability companies (društva s ograničenom odgovornošću), sole traders (trgovci pojedinci), European companies (SEs), European Economic Interest Groupings (EEIGs), European Cooperative Societies (SCEs), institutions (ustanove), communities of institutions (zajednice ustanova), cooperatives (zadruge), unions of cooperatives (savezi zadruga), credit unions (kreditne unije), simple limited liability companies (jednostavna društva s ograničenom odgovornošću) and other persons that have to be registered by law. Subsidiaries are entered in the register if this is required by law.

$28 \mathrm{EU}$ member states have different legal systems and they have as many different possibilities for companies. If you search through Business or Court register, or European company law in general, you can find that different issues concerning companies (such as rights and obligations of shareholders, capital, disclosure of information, etc.) are regulated through secondary legislation: directives and regulations ${ }^{24}$.

The Croatian company law and Court register aim to follow with technological developments throughout EU member states and European company law. The gold is to ensure that companies, citizens and authorities, take advantage of the possibilities offered by the digital age.

In Croatia, the main acts of legislation governing the establishment of entities subject to registration and their entry in the register are: The Court Register Act, The Companies Act ${ }^{25}$ and The Rules on the method of making an entry in the court register ${ }^{26}$. The data stipulated by law, and any changes to such data, are entered in the register on the basis of these laws. ${ }^{27}$

Digitalization of Court Register in Croatia has begun two decades before connection within BRIS. Court Register Act $^{28}$ was introduced in 1995 and since then has changed a number of times. Changes made in Court Register Act in 2007 have included, among other things, harmonization with EU law, although

24 Horak, Hana; Dumančić, Kosjenka; Poljanec, Kristijan: Modernizacija i usklađivanje prava društava u Republici Hrvatskoj sa pravnom stečevinom Europske unije i načelo transparentnosti podataka // Zbornik radova: II. Međunarodna konferencija Bosna i Hercegovina i euroatlantske integracije. Trenutni izazovi i perspektive. Bihać: Pravni fakultet Univerziteta u Bihaću; Centar za društvena istraživanja Internacionalnog Burč univerziteta, 2014. / Nevzet Veladžić et al. (ur.).

25 Official Gazette of the Republic of Croatia- Narodne novine no. 111/93, 34/99, 121/99, $52 / 00,118 / 03,107 / 07,146 / 08,137 / 09,125 / 11,152 / 11,111 / 12,68 / 13,110 / 15$

26 Official Gazette of the Republic of Croatia- Narodne novine no. 22/12

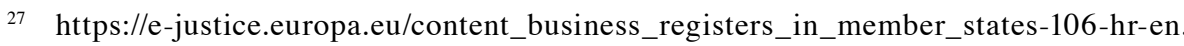
do?member=1 visited on Aug 28th, 2018

28 Ibid. 22 
Croatia wasn't EU member state ${ }^{29}$. Changes of Court Register Act dated from 26th April $2007^{30}$ included harmonization with Directive 2003/58/EC ${ }^{31}$. Croatia has pursued the gold of Directive 2003/58/EC and introduced the possibility that companies are able to choose to file their compulsory documents and particulars, by paper and by electronic means.

When establishing a company, applications may be filed electronically or as a hard copy. When changing the data of a company, than the application is filed as a hard copy only. Public announcements of the Court Register are made fully automatically in the database of the web page of court register. The court register at 8 commercial courts issues their decisions in automated processes through a central register.

The Court Register in Croatia contains the data of all Croatian business entities that are subject to registration (main register).

The documents which are relevant for registration are stored in the electronic archive of documents of the justice system (collection of documents) in the case of the establishment of a business entity through e-Tvrtka ${ }^{32}$ - but just for limited liability companies (društva s ograničenom odgovornošću) and simple limited liability companies (jednostavna društva s ograničenom odgovornošću). Other changes in data of business entities are not stored electronically (just in the paper). Registration can be carried out online but must be done by a notary and the registration number must be activated. The e-tvrtka system allows the filing of information electronically. Other changes of data of business entities cannot be changed electronically by e-tvrtka (just in the paper).

Company registration is the process of setting up a new legal entity that can account for profits, pay taxes. Newly-formed entity is legally and financially distinct from those who operate it. In order to set up and register a company, a number of essential (legal) documents are usually required by Court Register.

\footnotetext{
29 Croatia is EU member country since 1 July 2013

30 Official Gazette of the Republic of Croatia - no. 40/2007

31 Directive 2003/58/EC of the European Parliament and of the Council of 15 July 2003 amending Council Directive 68/151/EEC, as regards disclosure requirements in respect of certain types of companies $O J L 221,4.9 .2003$, p. 13-16

32 The e-tvrtka (e-Company) is implemented in collaboration of the Ministry of Justice, Central State office of e-Croatia, Commercial courts, Croatian Chamber of Public Notaries and Financial agency. It is based on the Instruction on the Conditions and Manner of Establishing Electronic Communication with the Court Registry (Official Gazette 40/07, 62/08, 107/08, 20/09) and its Changes and Supplements that require this service to be implemented by December 31st, 2009 to all Court registries in Croatia. By e-Company service, all Court registers became available from any HITRO.HR office or Public Notary office within Croatia enabling clients to have their company registered within 24 hours.
} 
These usually include a name, a company address, legal proof of the identity of the founder or director; Articles of association; a minimum deposited amount of capital. So in Croatia, which does not provide an end-to-end digital solution, checking the company name, notarizing Articles of Association, and filing the Articles at the Court Register takes approximately five to seven days.

In order to initiate the registration process, the applicant first has to make an application for registration in the court register. This can be done in paper or by electronic means. The commercial court decides if all formal requirements are fulfilled and if all necessary information is complete. On successful completion of this stage, the court includes the company in the court register. ${ }^{33}$ If an application for company registration takes place by notarial electronic official certified means: the official certified mean is the registration application protocol, which must be drafted by a notary and signed by the company director(s). The registration application protocol for limited liability companies must be accompanied by officially certified copies of the following documents: Company contract (which also has the notarial official certified deed); A list of directors (i.e. for d.d./d.o.o.) and board members (i.e. for d.d./d.o.o.); and a declaration that the directors and/or board members are not prohibited to exercise a profession in the sector of operation and that they have not been convicted of insolvency or economic crimes. These documents must accompany the application and are electronically transferred to the register court ${ }^{34}$, which require that document copies bear the electronic signature of the notary. The court then proceeds to publicize the entry in the commercial register, by electronic means ${ }^{35}$, on successful completion of the registration process. Digital tools are available for company registration in Croatia through the action of a notary. The notary must make use of an electronic communication platform for court communication. Notaries may communicate electronically with the court that is carrying out the registration, in accordance with their powers and the provisions of the $\operatorname{law}^{36}$. Given that the organization of the courts is a competence of the Ministry of Justice, the Ministry itself is mandated to set up an electronic system for company registration. There is a simplified procedure for registering a simple limited liability company (j.d.o.o. . $^{37}$ In order to be established in this way, such companies must use the forms drawn up by a notary.

\footnotetext{
Ibid 22. and 25.

Ibid 25.

35 Ibid. 22

36 Ibid 22

37 j.d.o.o.: a company with no more than three members, a one-member management board and minimum share capital of HRK 10.00
} 
The persons that are authorized to submit applications for entry in the register are: 1. Notaries (who are authorized to submit applications electronically and to issue extracts, copies and transcripts) ${ }^{38} ; 2$. Persons who are authorized by law to propose entries in the register (personally or through an authorized representative), 3. Persons who deal with matters of HITRO.HR offices (who are authorized to submit applications for the establishment of trading companies via the e-Tvrtka system, in accordance with the powers laid down in separate regulations).

An entry takes legal effect for the registered entity on the day following the entry in the register (except where the law provides otherwise) and takes legal effect for third parties on the day on which it is published. No person may claim that they do not know data entered in the general book of the register which has been published in the manner stipulated by the law ${ }^{39}$. Any person may cite an entry in the register regarding legally settled data and facts which are entered in the register in accordance with the law, except for a person who is proved to have known that the relevant data in the entry in the register did not correspond to reality. The actions undertaken by a third party before the sixteenth day following the date of publication of an entry in the register may not be opposed on the basis of the registered data or the documents referred to in the publication, if the third party can prove that he/she/it could not have known about them. A person of good faith may not suffer damage for having relied on an entry in the register regarding legally settled data and facts.

The Court Register is constantly upgraded and technologically adapted to recent developments and current conditions.

Court's Register documents are served by post or personally to the parties. The Court Register also uses data of the Ministry of Finance for OIB (personal identification number) when establishing a company. Electronic submission of annual financial statements to the Business Register was introduced in 2007. Thus, all relevant documents are not available electronically, which doesn't allow completely digital file management in Court Register proceedings.

Court Register data may be retrieved through the internet at www.sudreg.pravosudje.hr. In Croatia information for an active, as for passive/deleted companies, are available permanently in the court register.

Since 2013 all data have been published on the internet and are legally binding as such. This has led to a reduction in publication costs of $95 \%$. Through the internet, every internet user can view the current status free of charge. "At the

under Article 4(2) ZSR

39 Ibid 22. 
touch of a button" data is transferred automatically from the court register Database.

At the moment, the company representatives cannot file documents fully online. They need to go in person in front of a notary who certifies the documents and then submits them online to the court register. But the Ministry of Justice works on amendments of several acts to achieve completely online registration for certain types of companies ${ }^{40}$.

Without having to prove a legitimate interest, anyone is entitled to examine the information entered in the general book, the documents on which an entry is based and the other documents and information stored in the collection of documents (except for documents that the law states are not subject to the public-domain principle). Anyone may also request an extract, a certified copy or a transcript of documents and data stored in the collection of documents.

The ownership information available in the register differs depending on the type of company: ownership information on joint stock companies is available only where there is only one shareholder, while the identity of all members of limited liability companies is entered in the Register (name, address, and unique personal identification number of all their members). This is due to the different nature of the two types of entities: the ownership of joint stock companies is much more flexible in practice and shareholding can change every day for those that are listed on a stock exchange. The ownership information is available with the company itself, in the shareholders' register, and through securities accounts.

Since June 2017 the Croatian Court Register has been linked with other European registers via BRIS ${ }^{41}$ (Business Registers Interconnection System). Focused on corporations the system features Europe-wide search functions and document queries as well as notifications of insolvencies, liquidations and mergers. Croatia was one of the first ten EU member states introduced with BRIS. Through e-Justice Portal, you can search for information on companies registered in Croatia $^{42}$ (and 9 other countries). You can access to all basic information free of charge-name of company, companies' registers number, seat, country, EUID, etc. But that is not enough.

40 Online registration is expected to be in force in the first half of 2019.

$41 \quad$ Ibid 1

42 https://sudreg.pravosudje.hr/ 
OVERVIEW of establishing companies (entries of entities) through different channels: hitro.hr, public notaries and direct court; Source: IN2

\begin{tabular}{|l|r|r|c|}
\hline \multicolumn{1}{|c|}{ HITRO.hr } & \multicolumn{1}{c|}{2016} & 2017 & 1.1-30.6. 2018 \\
\hline Commercial court in Bjelovar & 201 & 200 & 119 \\
\hline Commercial court in Osijek & 293 & 364 & 217 \\
\hline Commercial court in Rijeka & 279 & 263 & 149 \\
\hline Commercial court in Split & 133 & 155 & 100 \\
\hline Commercial court in Varaždin & 547 & 533 & 297 \\
\hline Commercial court in Zagreb & 1297 & 1837 & 1094 \\
\hline Commercial court in Zadar & 135 & 127 & 90 \\
\hline Commercial court in Pazin & 293 & 320 & 190 \\
\hline Commercial court in Zagreb - branch Karlovac & 2 & 7 & 4 \\
\hline Commercial court in Osijek - branch Sl. Brod & 43 & 38 & 25 \\
\hline Commercial court in Split - branch Dubrovnik & 4 & 3 & 2 \\
\hline Commercial court in Zadar - branch Šibenik & 9 & 7 & 9 \\
\hline & $\mathbf{3 2 3 6}$ & $\mathbf{3 8 5 4}$ & $\mathbf{2 2 9 6}$ \\
\hline
\end{tabular}

\begin{tabular}{|l|r|r|c|}
\hline \multicolumn{1}{|c|}{ PUBLIC NOTARIES } & 2016 & 2017 & $1.1-30.6 .2018$. \\
\hline Commercial court in Bjelovar & 13 & 10 & 5 \\
\hline Commercial court in Osijek & 322 & 381 & 194 \\
\hline Commercial court in Rijeka & 688 & 790 & 421 \\
\hline Commercial court in Split & 972 & 1057 & 692 \\
\hline Commercial court in Varaždin & 318 & 379 & 189 \\
\hline Commercial court in Zagreb & 1763 & 1777 & 890 \\
\hline Commercial court in Zadar & 434 & 489 & 298 \\
\hline Commercial court in Pazin & 669 & 697 & 347 \\
\hline Commercial court in Zagreb - branch Karlovac & 6 & 7 & 4 \\
\hline Commercial court in Osijek - branch Sl. Brod & 5 & 6 & 2 \\
\hline Commercial court in Split - branch Dubrovnik & 11 & 3 & 3 \\
\hline Commercial court in Zadar - branch Šibenik & 101 & 177 & 122 \\
\hline & $\mathbf{5 3 0 2}$ & $\mathbf{5 7 7 3}$ & $\mathbf{3 1 6 7}$ \\
\hline
\end{tabular}




\begin{tabular}{|l|r|r|c|}
\hline $\begin{array}{c}\text { APPLICATIONS direct to register court } \\
\text { (including bankruptcy masses entities) }\end{array}$ & 2016 & 2017 & $1.1-30.6 .2018$ \\
\hline Commercial court in Bjelovar & 241 & 221 & 126 \\
\hline Commercial court in Osijek & 659 & 594 & 275 \\
\hline Commercial court in Rijeka & 756 & 804 & 287 \\
\hline Commercial court in Split & 707 & 709 & 332 \\
\hline Commercial court in Varaždin & 437 & 333 & 103 \\
\hline Commercial court in Zagreb & 4212 & 4096 & 2215 \\
\hline Commercial court in Zadar & 297 & 225 & 71 \\
\hline Commercial court in Pazin & 758 & 566 & 178 \\
\hline Commercial court in Zagreb - branch Karlovac & 240 & 218 & 135 \\
\hline Commercial court in Osijek - branch Sl. Brod & 313 & 331 & 163 \\
\hline Commercial court in Split - branch Dubrovnik & 385 & 409 & 214 \\
\hline Commercial court in Zadar - branch Šibenik & 247 & 139 & 66 \\
\hline & $\mathbf{9 2 5 2}$ & $\mathbf{8 6 4 5}$ & $\mathbf{4 1 6 5}$ \\
\hline
\end{tabular}

\section{SITUATION IN OTHER COUNTRIES}

Company registration operations across the Member States are diverse ${ }^{43}$. The types of digital tools made available for such operations vary from country to country. However, all countries allow for the use of digital tools for company registration operations. In some countries ${ }^{44}$ these available tools allow for the direct, end-to-end registration of companies, whereas in others ${ }^{45}$ intermediaries must handle the electronic systems made available. Digital tools for company registration and dissolution, filing and sharing of company information, and mergers are made available (or not) through a variety of legal and practical vehicles.

The EU offers a very inconsistent landscape when it comes to the availability of online tools for companies in their contact with public authorities in the area of company law ${ }^{46}$. Member states provide e-government services at vari-

\footnotetext{
43 Assessment of the impacts of using digital tools in the context of cross-border company operations - Final Report, December 2017

44 Portugal and Estonia

45 Germany

46 Commission staff working document impact assessment accompanying the document Proposal for a Directive of the European Parliament and of the Council amending Directive (EU) 2017/1132 as regards the use of digital tools and processes in company law and Proposal for a Directive of the European Parliament and of the Council amending Directive (EU) 2017/1132
} 
able degrees: some are very advanced and provide easy-to-use, fully online solutions ${ }^{47}$, while others are more timid in their efforts and do not offer at all online solutions for critical steps in a company's lifecycle such as the registration of the company as a legal entity.

Certain digital processes are not covered at all by EU law and only a number of member states address them at the national level. For example, today (only) 17 member states ${ }^{48}$ provide a procedure for the fully online registration of companies; in the other member states the only way to register a company is by going in person to the registration authority or another body which then submits the application for registration ${ }^{49}{ }^{50}$, while some member states ${ }^{51}$ require only facultative involvement of notaries.

Once they have been registered, companies and branches have an obligation to file certain information with the business registers during their lifetime (for example, amendments to their articles of the constitution, changes in the names of company legal representatives or their annual accounts $)^{52}$. Although the current EU law stipulates that companies should be able to submit the documents and particulars that are part of the mandatory disclosure requirements "by electronic means" 53 , the current definition of "electronic means" is not specific enough and leads to a diverse implementation in the member states.

Once companies and branches have filed the necessary information with the business registers, current EU rules provide for the publication of all or part of that information in the national gazette ${ }^{54}$. It is only by publication in the national gazette (or equally effective means) that the disclosed information becomes legally effective. Such requirement dates back to the early days of EU company law $^{55}$ when the publication in the official gazette was the only way of

as regards cross-border conversions, mergers and divisions COM(2018) 239 final - COM(2018) 241 final - SWD(2018) 142 final

47 . A number of business registers already have in place advanced online tools and solutions, for example Denmark, Estonia, Latvia

48 Bulgaria, Denmark, Estonia, Finland, France, Italy, Ireland, Latvia, Lithuania, Malta, Poland, Portugal, Romania, Slovakia, Slovenia, Sweden, and the UK.

49 Belgium, Germany, Hungary, Spain, Croatia

50 Study on digitalization of company law, Everis, 2017

51 Estonia, Poland

52 Ibid. 43

53 Article 16(2) of Directive (EU) 2017/1132

$54 \quad$ Ibid. 22

55 The first company law directive was adopted in 1968 and some of the requirements, such as the publication in the national gazette, were introduced then. 
ensuring certainty and transparency of business information. A revision of the EU rules in $2003^{56}$ introduced the option for member states to keep the national gazette in electronic form, without specifying how the information should be submitted by the company and in particular it did not do away with possible multiple submission requirements in the member state.

Concerning access by third parties to company information in business registers, the directive ${ }^{57}$ on the interconnection of business registers (BRIS) sets a minimum set of data which must always be provided for free ${ }^{58}$. However for the other company information available in the business registers most member states charge fees for all or some of that information ${ }^{59}$. Although this is in line with the existing EU rules which state that member states can charge fees which cannot exceed the administrative cost of storing and maintaining that data, this means that access to information varies across the EU, with more information being available free of charge in some member states than in others.

\subsection{DIRECT END-TO-END MANNER}

In Estonia the Commercial Code allows company registration operations to be done online through the Company Registration Portal ${ }^{60}$. For the registration of limited liability companies through the Company Registration Portal ${ }^{61}$, the applicant needs to be in possession of an Estonian ID-card (Latvian, Belgian, Finnish, and Lithuanian ID cards or mobile IDs are also acceptable) for identification and digital signature authentication purposes. In France, company registration is available through the "centres des formalités des entreprises $(C F E)$ ". A person wishing to register a company needs to provide information

\footnotetext{
56 Directive 2003/58/EC of the European Parliament and of the Council of 15 July 2003 amending Council Directive 68/151/EEC, as regards disclosure requirements in respect of certain types of companies, OJ L 221, 04/09/2003 P. 13-16. It was the same directive that also introduced the possibility for companies to file documents online.

57 Directive 2012/17/EU of the European Parliament and of the Council of 13 June 2012 amending Council Directive 89/666/EEC and Directives 2005/56/EC and 2009/101/EC of the European Parliament and of the Council as regards the interconnection of central, commercial and companies registers Text with EEA relevance, OJ L 156, 16.6.2012, p. 1-9

58 This includes the company name, registered office, legal form, company registration number and the Member State in which the company is registered.

59 Only six member states provide all information free of charge: Belgium, Bulgaria, Czech Republic, Luxembourg, Slovenia, and the UK

60 Ibid. 43

${ }_{61}$ Companies can be registered directly through the Company Registration Portal, available online at: https://ettevotjaportaal.rik.ee/
} 
through the CFE online portal, which then transmits the full file to the registry of the concerned commercial court or chamber of handicraft. The verification of the files is then performed either by the online portal or by the registry of the commercial court or chamber of handcraft. The CFE also transmits the file to the concerned authorities, in particular, the tax and social contributions authorities. In Portugal in order to create and register a limited liability company through the Citizen's Portal ${ }^{62}$, the applicant(s) must have a Citizen's Card. Applicants of a nationality other than Portuguese have to obtain a Fiscal Identification Number from the Portuguese Financial Services Authority. Estonian and Spanish nationals can use their corresponding ID cards and are exempt from this pre-requirement. In Poland, the Polish Commercial Companies Code provides for the possibility to register limited liability companies in a simplified manner without the need for intervention by a notary. However, there is one exception to this provision: if the share capital contribution to a company is to be made as a non-cash contribution, the company registration process must be carried out in the traditional manner that is signing a notary act.

\subsection{INTERMEDIARIES ARE REQUIRED}

In Italy, company registration must be preceded by company creation. For limited liability companies, the company creation process cannot be carried out electronically and requires signing the articles of association as a public deed before a notary. The company registration process can be carried out electronically in a direct, end-to-end fashion using the ComUnica system, as long as applicants are in possession of a certified email address, a username and password from the Business Registry, a smart-card or USB key for authenticated digital signatures. In the case of 'innovative start-ups', such start-ups are not required to sign their articles of association before a notary but using their digital signature. In Germany, the process is dependent on the action of a notary, so there's not a direct, end-to-end. Some digital tools are available for company registration in Germany ${ }^{63}$. The notary must make use of the electronic communication platform for court communication ${ }^{64}$. Given that the organization of the courts is a competence of the states ${ }^{65}$, the justice ministries of the different states are mandated to set up an electronic system for company registration: each state issued executive regulation to make the use of electronic commu-

\footnotetext{
62 https://www.portaldocidadao.pt

63 Assessment of the impacts of using digital tools in the context of cross-border company operations Final Report, December 2017

${ }^{64}$ Elektronisches Gerichts- und Verwaltungspostfach

65 Länder
} 
nication mandatory for company registration. As such, companies are registered in the commercial register ${ }^{66}$ which is kept by the registration courts ${ }^{67}$. The entries in the register are kept electronically. Registration is obligatory for limited liability companies ${ }^{68}$ which have legal personality. In the Netherlands, in order to proceed with the electronic company registration process, notary offices must request a certification key from the notary chamber and a PKI certificate from the Chamber of Commerce ${ }^{69}$. Additionally, no electronic registration is possible for cross-border company registration, and the whole process must be carried out through paper forms. Applicants must also provide further official certified copies of specific documentation in order to initiate the process. The registration of limited liability companies can only be filed electronically by a notary. This electronic registration takes place through the use of an online platform hosted by the Chamber of Commerce. Intermediaries are required for the registration of limited liability companies. The process, therefore, cannot be considered to be direct or end-to-end. In Hungary, all the required documentation necessary for registering a company can be pooled together in E-acta. Electronic documents must be authenticated by means of qualified electronic signatures and time stamping ${ }^{70}$. However, legal representation is necessary to carry out these processes. All the documentation submitted to County Courts must be countersigned by an attorney who possesses the required digital signature and time-stamp platforms. Legal representation is mandatory with obligatory technical safeguards. However, the process itself is entirely digitalized.

\footnotetext{
Handelsregister

Handelsgesetzbuch - Commercial Code

$\mathrm{AG}, \mathrm{GmbH}$

Kamer van Koophandel

70 E-Szignó
} 
OVERVIEW OF THE MAIN AUTHORITIES INVOLVED IN COMPANY LAW

\begin{tabular}{|c|c|c|c|c|}
\hline country & $\begin{array}{c}\text { notary } \\
\text { (or lawyer) }\end{array}$ & $\begin{array}{l}\text { Business } \\
\text { Register }\end{array}$ & $\begin{array}{c}\text { Local Commercial } \\
\text { Court }\end{array}$ & $\begin{array}{l}\text { One Stop } \\
\text { Shop }\end{array}$ \\
\hline Austria & $\mathbf{X}$ & & $\mathbf{X}$ & $\mathbf{X}$ \\
\hline Belgium & $\mathbf{X}$ & $\mathbf{X}$ & $\mathbf{X}$ & $\mathbf{X}$ \\
\hline Bulgaria & $\mathbf{X}$ & $\mathbf{X}$ & & $\mathbf{X}$ \\
\hline Croatia & $\mathbf{X}$ & & $\mathbf{X}$ & \\
\hline Cyprus & $(\mathbf{X})$ & $\mathbf{X}$ & & $\mathbf{X}$ \\
\hline Czech R. & $\mathbf{X}$ & $\mathbf{X}$ & $\mathbf{X}$ & \\
\hline Denmark & & $\mathbf{X}$ & & $\mathbf{X}$ \\
\hline Estonia & & $\mathbf{X}$ & $\mathbf{X}$ & $\mathbf{X}$ \\
\hline Finland & & $\mathbf{X}$ & & $\mathbf{X}$ \\
\hline France & & & $\mathbf{X}$ & $\mathbf{X}$ \\
\hline Germany & $\mathbf{X}$ & $\mathbf{X}$ & & \\
\hline Greece & & $\mathbf{X}$ & & $\mathbf{X}$ \\
\hline Hungary & $(\mathbf{X})$ & & $\mathbf{X}$ & \\
\hline Ireland & & $\mathbf{X}$ & & \\
\hline Italy & $\mathbf{X}$ & $\mathbf{X}$ & & $\mathbf{X}$ \\
\hline Latvia & $\mathbf{X}$ & & & \\
\hline Lithuania & & $\mathbf{X}$ & & $\mathbf{X}$ \\
\hline Luxembourg & $\mathbf{X}$ & & & $\mathbf{X}$ \\
\hline Malta & $\mathbf{X}$ & $\mathbf{X}$ & & \\
\hline Netherlands & $\mathbf{X}$ & & & \\
\hline Poland & $\mathbf{X}$ & $\mathbf{X}$ & & \\
\hline Portugal & & $\mathbf{X}$ & & $\mathbf{X}$ \\
\hline Romania & & $\mathbf{X}$ & & $\mathbf{X}$ \\
\hline Slovakia & $\mathbf{X}$ & & $\mathbf{X}$ & $\mathbf{X}$ \\
\hline Slovenia & & & & $\mathbf{X}$ \\
\hline Spain & $\mathbf{X}$ & $\mathbf{X}$ & & $\mathbf{X}$ \\
\hline Sweden & $\mathbf{X}$ & $\mathbf{X}$ & & $\mathbf{X}$ \\
\hline The U.K. & & $\mathbf{X}$ & & $\mathbf{X}$ \\
\hline
\end{tabular}

Source: World Bank/Doing Business

Filing and disclosure of company information is also diverse process across the Member States. The type of digital tools made available for such operations also varies from country to country. However, all countries allow for some form of a digital tool for filing and disclosure of company information. 
In some countries, this can be done through a dedicated online portal ${ }^{71}$ whereas in others it requires input from the commercial registries ${ }^{72}$.

\section{THE FUTURE IN CROATIA}

One of the ways to overcome the difficulties regarding the decisions based on the state of companies' registers is their networking at the $\mathrm{EU}^{\text {level }}{ }^{73}$.

Why is the enhanced cooperation of business registries needed ${ }^{74}$ The interconnection of business registers serves two distinct but related purposes:

1. Access to information - the network of business registers: Facilitating access to information on companies across borders increases transparency in the Single Market enhances the protection of shareholders and third parties and helps to restore confidence in the markets. Cross-border access to information has been promoted significantly by the entry into force of the 2003 amendment of the First Company law Directive ${ }^{75}$ that introduced electronic business registers in the Member States as of 1 January 2007. However, citizens and businesses still have to search in at least 27 registers in order to gather the relevant business information on companies. Even if the registers are available online, stakeholders have to deal with different languages, search conditions, structures. A single access point to business information on all European companies could save time and costs for businesses. Therefore it is now time to think about the next steps in this process. First and foremost, all Member States should participate in the cooperation and in taking decisions about its terms and conditions. It should be possible to access reliable information on companies in all Member States, preferably in all official languages of the EU. It should also be possible to search for information on a company or a group of companies active in different Member States without having to access the relevant national or regional registers one-by-one. The quality of service should be at the same level across the EU.

\footnotetext{
71 Portugal, Estonia

72 Luxembourg, Netherlands

73 Horak, Hana; Dumančić, Kosjenka; Poljanec, Kristijan: The Interconnection of Company Data - a Way Forward in Development of Freedom of Establishment? // European Journal of Economics and Management, 3 (2016), 1; 134-152

74 Green Paper - The interconnection of business registers $\{\operatorname{SEC}(2009) 1492\} / *$ COM /2009/0614 final */

75 Directive 2003/58/EC of the European Parliament and of the Council of 15 July 2003 amending Council Directive 68/151/EEC, as regards disclosure requirements in respect of certain types of companies OJ L 221, 4.9.2003, p. 13-16
} 
2. Cooperation of business registers in cross-border procedures: The second purpose of the interconnection of business registers is to strengthen cooperation in the case of cross-border procedures, such as cross-border mergers, seat transfers or insolvency proceedings. Such cross-border cooperation is required by several company law instruments.

In Croatia, the Court Register documentation (collection of documents) is in the paper. Just a small percentage of documentation is digitalized. The Court Register documentation has to be migrated from basement and old paper to IT-based systems. It is necessary to migrate the collection of documents of the court register to the electronic storage of electronic documents. That's the first step. The technology for archiving documents has made considerable progress. Voices among those who are practicing law have shown the necessity to modernize the court system with the assistance of information technology also in this area. A central archive of documents should emerge, which can be used for all types of applications, proceedings, and procedures. It would be practical to have the possibility to archive documents (e.g. electronically signed contracts) from the court in a database in any application and in any type of proceedings and to establish a link to the same. In this way, a document once stored in the archive could be used in different legal proceedings.

The data content stored in the electronic documents archive is deemed the original of the document until the contrary is proved. In this way, another step towards optimized and service-oriented legal proceedings will be implemented.

\section{CONCLUSION AND SOLUTION}

I've read at one Finish blog: "Digitalization is a hot topic not only because it sounds like a "cool thing" to do, but also because it is probably one of the first true revolutions in business history." It's something like the industrial revolution in the mid-18th century. And much more.

We would highlight that European and national company law needs to keep pace with technological developments in order to ensure that companies, citizens and authorities fully benefit from the possibilities offered by the digital age. Two words describe future digital age: quick and simple. The EU works on quicker and simpler access to information on companies.

Considering Croatia, it's important to stress two things: the necessity of electronic, digital documents archive in the court register and the importance of the notary's role in ensuring legal certainty in the course of the process of the registration of company operations (and its changes). 
First, the electronic, digital documents archive of court register documents is needed. Badly. We wait for ages. It would be much easier, quicker and simpler to have electronic, digital documents archive when dealing with changes of business entities. One should have in mind that issues that might undermine the perception that company law operations, when carried out through less traditional, digital mediums, are as legally valid and likely to be authentic, or at least, as when they had been done using paper. One should analyze and focus it on issues surrounding the security and authenticity of legal documents, and how to ensure that, in the instance where a document is not submitted in person, it was submitted by the individual who claimed to submit it, and that they had the authority to act on behalf of the company they claimed to represent. In addition to ensuring the authenticity of legal documents, one should focus on issues storing such large volumes of legal documents and ensuring that they are secure. It is essential for the smooth functioning of the court register that there is the perception of certainty of legal documents as being accurate and binding.

To point out: the use of electronic, digital documents archive is very important to facilitate incorporation and all changes during the life of a company.

Second, the most important task of the notary is the verification and certification of the identity of the person, who conducts the company operation. The notary ensures that all legal requirements (e.g. form and content of the company contracts, the requirements on the company capital, directors, etc.) with regard to company operations will be fulfilled. This aspect of the notary's role must be seen in connection with the notary's obligation to give counseling and legal advice to the persons conducting the company operation.

To point out: the main enforcer of legal certainty in the processes underlying each company law operation is the action of notaries. It was also noted that the current digital tools used by notaries result in a positive impact directly related to increased transparency of information.

The European Commission is still working on a Business Register Interconnection, service which is intended to provide the possibility to search for companies and corporations and to obtain commercial or business register excerpts. The result of the work of BRIS is not yet apparent and there is a space for business registers to cooperate further to share the best practice.

Diversity creates inefficiencies and an uneven playing field for companies as some member states only allow for the face-to-face procedure for company registration while others allow both face-to-face and online procedure or only online. But what is wrong with diversity? Uniformity is not a solution for every challenge. Digitalization is both: a challenge and an opportunity. 
The use of digital tools in company law is very important to facilitate incorporation, changes, etc. However, with the use of technology come risks such as a security breach and other matters. Therefore, it is important for the public authority to play a role in the incorporation and even human intervention at some point along with the point of registration. Also, very important to point out is that the law and the authorities administering the law, besides that they shouldn't favor any one technology, they shouldn't be subaltern to technology. Instead, technology should be in a function of the law, a law should benefit from it.

\section{LITERATURE}

1. Horak, Hana; Dumančić, Kosjenka; Poljanec, Kristijan; Vuletić, Dominik: European Market Law - Handbook (Vol.I) Voronezh/Zagreb: Voronezh State University, Faculty of Law; University of Zagreb, Faculty of Economics and Business, 2014.

2. Horak, Hana; Dumančić, Kosjenka; Poljanec, Kristijan: European Market Law Textbook, Vol. 1. / Horak, Hana (ur.)., Zagreb: Ekonomski fakultet Sveučilišta u Zagrebu, 2015.

3. Horak, Hana; Dumančić, Kosjenka; Pecotić Kaufman, Jasminka: Uvod u europsko pravo društava, Zagreb: Školska knjiga, 2010.

4. Horak, Hana; Dumančić, Kosjenka; Poljanec, Kristijan: The Interconnection of Company Data - a Way Forward in Development of Freedom of Establishment? // European Journal of Economics and Management, 3, 2016, 1; p. 134-152

5. Horak, Hana; Dumančić, Kosjenka; Poljanec, Kristijan: Principle of Transparency as Integrative Factor of the Internal Market and Harmonisation of Croatian Law on Companies Registries. // International law readings, 2014., 14; p. 170-195

6. Horak, Hana; Dumančić, Kosjenka, Transparency and Disclosure as key elements for companies and markets u: Horak, Hana (ed.), 2nd International Conference: Legal and Economic Aspects of Corporate Governance - Market Transparency and Disclosure in Private and Public Companies, Proceedings, Zagreb, 2013.

7. Horak, Hana; Dumančić, Kosjenka: Harmonisation of the Croatian Company Law with acquis communitare of the European Union u: Horak, Hana; Bodiroga Vukobrat Nada; Dumančić, Kosjenka; Šafranko, Zvonimir (ur.), Hrvatsko i europsko pravo društava/Croatian\&European Company Law, Zbornik radova/ Proceedings, Zagreb, 2012. - Horak, Hana; Dumančić, Kosjenka, Usklađivanje u području prava društava Republike Hrvatske s pravnom stečevinom EU, Pravo i porezi, 20:5/2011, p. 86-93

8. Bregeš, Željka; Jakupak, Tina (2017): Digitalization of Business register, InterEULawEast: journal for the international and European law, economics and market integrations, Volume 4, No. 2, December 2017., p. 91-99

- DOI: https://doi.org/10.22598/iele.2017.4.2.6 
9. Directive (EU) 2017/1132 of the European Parliament and of the Council of 14 June 2017 relating to certain aspects of company law, OJ L 169, 30.6.2017, p. $46-127$

10. Directive 2012/17/EU of the European Parliament and of the Council of 13 June 2012 amending Council Directive 89/666/EEC and Directives 2005/56/EC and 2009/101/EC of the European Parliament and of the Council as regards the interconnection of central, commercial and companies registers, OJ L 156, 16.6.2012, p. $1-9$

11. Directive 2009/101/EC of the European Parliament and of the Council of 16 September 2009 on coordination of safeguards which, for the protection of the interests of members and third parties, are required by Member States of companies within the meaning of the second paragraph of Article 48 of the Treaty, with a view to making such safeguards equivalent, OJ L 258, 1.10.2009, p. 11-19., no longer in force

12. Directive 2003/58/EC of the European Parliament and of the Council of 15 July 2003 amending Council Directive 68/151/EEC, as regards disclosure requirements in respect of certain types of companies OJ L 221, 4.9.2003, p. 13-16

13. Companies Act (Official gazette111/93, 34/99, 121/99, 52/00, 118/03, 107/07, $146 / 08,137 / 09,125 / 11,152 / 11,111 / 12,68 / 13,110 / 15)$

14. Court Register Act (Official Gazette 1/95, 57/96, 1/98, 30/99, 45/99, 54/05, 40/07, 91/10, 90/11, 148/13, 93/14, 110/15)

15. Green Paper - The interconnection of business registers $\{\operatorname{SEC}(2009) 1492\} / *$ COM /2009/0614 final

16. Final Report - Assessment of the impacts of using digital tools in the context of cross-border company operations, Everis, December 2017

17. COMMISSION STAFF WORKING DOCUMENT IMPACT ASSESSMENT Accompanying the document Proposal for a Directive of the European Parliament and of the Council amending Directive (EU) 2017/1132 as regards the use of digital tools and processes in company law and Proposal for a Directive of the European Parliament and of the Council amending Directive (EU) 2017/1132 as regards cross-border conversions, mergers and divisions COM(2018) 239 final COM(2018) 241 final - SWD(2018) 142 final

\section{ONLINE SOURCES}

1. https://sudreg.pravosudje.hr/

2. http://www.europarl.europa.eu/RegData/etudes/IDAN/2016/556961/IPOL_ IDA(2016)556961_EN.pdf

3. http://ec.europa.eu/justice/civil/files/company-law/icleg-report-on-digitalisation-24-march-2016_en.pdf 
4. http://europa.eu/youreurope/business/start-grow/start-ups/index_en.htm

5. http://eur-lex.europa.eu/legal-content/EN/TXT/PDF/?uri=CELEX:52014SC 0124\&from $=E N$

6. http://ec.europa.eu/justice/events/company-law 2015/files/20151002 _cvj_speech_ company_law_sc_en.Pdf

7. https://www.justiz.gv.at/web2013/home/e-government/firmenbuch/

8. http://economie.fgov.be/fr/entreprises/BCE/

9. http://kbopub.economie.fgov.be/kbopub/zoeknummerform.html

10. http://www.brra.bg/

11. https://or.justice.cz/ias/ui/rejstrik

12. http://www.mcit.gov.cy/

13. https://datacvr.virk.dk/

14. https://ariregister.rik.ee/index.py?lang=eng

15. http://www.prh.fi/en/index.html

16. http://www.infogreffe.fr/

17. http://www.handelsregister.de/

18. http://www.unternehmensregister.de/

19. http://www.businessportal.gr/

20. https://occsz.e-cegjegyzek.hu/info/page/ceginfo

21. http://www.rsk.is/

22. https://www.cro.ie/

23. http://www.registroimprese.it/

24. http://www.ur.gov.lv/

25. http://www.oera.li/hrweb/ger/firmensuche_afj.htm

26. http://www.registrucentras.lt/jar/

27. http://www.rcsl.lu/

28. http://registry.mfsa.com.mt/

29. https://www.kvk.nl/english/business-register/

30. https://www.brreg.no/

31. http://bip.ms.gov.pl/pl/rejestry-i-ewidencje/krajowy-rejestr-sadowy/

32. http://www.irn.mj.pt/

33. http://www.onrc.ro/ 
34. http://www.orsr.sk/

35. http://www.ajpes.si/prs/

36. http://www.registradores.org/

37. http://www.bolagsverket.se/

38. http://www.companieshouse.gov.uk/ 